\title{
Does body mass play a role in the regulation of food intake?
}

\author{
John R. Speakman ${ }^{1,2 *}$, R. James Stubbs ${ }^{1}$ and Julian G. Mercer ${ }^{1}$ \\ ${ }^{1}$ Aberdeen Centre for Energy Regulation and Obesity, Division of Appetite and Energy Balance, \\ Rowett Research Institute, Aberdeen AB21 9SB, UK \\ ${ }^{2}$ Department of Zoology, University of Aberdeen, Aberdeen AB9 2TZ, UK
}

\begin{abstract}
It is widely believed that body fatness (and hence total body mass) is regulated by a lipostatic feedback system. This system is suggested to involve at least one peripheral signalling compound, which signals to the brain the current size of body fat stores. In the brain the level of the signal is compared with a desirable target level, and food intake and energy expenditure are then regulated to effect changes in the size of body fat stores. There is considerable support for this theory at several different levels of investigation. Patterns of body-mass change in subjects forced into energy imbalance seem to demonstrate homeostasis, and long-term changes in body mass are minor compared with the potential changes that might result from energy imbalance. Molecular studies of signalling compounds have suggested a putative lipostatic signal (leptin) and a complex network of downstream processing events in the brain, polymorphisms of which lead to disruption of body-mass regulation. This network of neuropeptides provides a rich seam of potential pharmaceutical targets for the control of obesity. Despite this consistent explanation for the observed phenomena at several different levels of enquiry, there are alternative explanations. In the present paper we explore the possibility that the existence of lipostatic regulation of body fatness is an illusion generated by the links between body mass and energy expenditure and responses to energy imbalance that are independent of body mass. Using computer-based models of temporal patterns in energy balance we show that common patterns of change in body mass following perturbation can be adequately explained by this 'non-lipostatic' model. This model has some important implications for the interpretations that we place on the molecular events in the brain, and ultimately in the search for pharmaceutical agents for alleviation of obesity.
\end{abstract}

Lipostat: Energy homeostasis: Set-point: Body fatness: Leptin

Thesis: body mass is regulated by a 'lipostatic' regulation system

\section{A whole-body perspective}

It has been observed on many occasions that very small alterations in our energy balance at the whole-body level, if they are continued over long time periods, can potentially lead to enormous changes in body mass (for example, see Weigle, 1994; St Jeor, 1997). For example, on average an apple contains about $200 \mathrm{~kJ}$ ( $50 \mathrm{kcals})$. If, over a period of 25 years, a subject ate one apple per $\mathrm{d}$ more than their energy expenditure it would lead to the accumulation of $25 \times 365 \times 200 \mathrm{~kJ}(1825 \mathrm{MJ})$ energy that would be stored as fat. Since $1 \mathrm{~kg}$ adipose tissue contains about $800 \mathrm{~g}$ lipid $(39 \mathrm{MJ} / \mathrm{kg}$ ), and thus contains about $33 \cdot 1 \mathrm{MJ}$ energy (Forbes,
1987), the $1825 \mathrm{MJ}$ excess accumulated energy would be equivalent to approximately $55 \mathrm{~kg}$ adipose tissue. Just eating one apple per $d$ in excess of daily energy requirements would lead to the development of excessive obesity. This calculation is even more remarkable if we consider that a typical candy bar contains about $1000 \mathrm{~kJ}(250 \mathrm{kcals})$. Eating just one candy bar every $5 \mathrm{~d}$, above expenditure, would lead to the same accretion of body fatness. These calculations have become part of the established wisdom about the causes of obesity. For example, the Center for Disease Control public health perspectives website in the USA (http://www.cdc.gov/genomics/info/perspectives/files /obesknow.htm) contains the statement 'Overweight and obesity can result from only a very small positive energy input imbalance over a long period of time', and the UK

\footnotetext{
Abbreviations: AGRP, agouti-related peptide; CART, cocaine- and amphetamine-regulated transcript; NPY, neuropeptide Y; PA, physical activity; NEAT, non-physical activity.

*Corresponding author: Professor J. R. Speakman, fax +44 1224 716686, email J.Speakman@rri.sari.ac.uk
} 
Medical Research Council website (http://www.nimr.mrc. ac.uk/MillHillEssays/1995/ob.htm) contains a more explicit statement 'Fat people have over a period of time eaten too much relative to their needs. Even a slight sustained excess in daily energy intake, such as the calorie content of a single chocolate biscuit, will result in one kilogram weight gain in a year'.

If we take as the starting point for this calculation a subject weighing $70 \mathrm{~kg}$ with a daily energy expenditure of about $10 \mathrm{MJ}$, then the extent of imbalance reflected by an extra apple every day $(200 \mathrm{~kJ})$ is about $2 \%(200 / 10000)$. Yet, it is extremely unusual for a subject at age 20 years, weighing $70 \mathrm{~kg}$, to weigh in at $125 \mathrm{~kg} 25$ years later when they are aged 45 years, having achieved the accumulation of $55 \mathrm{~kg}$ adipose tissue. This situation suggests that normally the balance between energy expenditure and energy intake over very long time periods is extremely precise, with the difference between expenditure and intake routinely amounting to only $0 \cdot 2 \%$ of the total of either intake or expenditure over 25 years (Weigle, 1994; Friedman, 2000). The implication is that our food intake must be under regulated control, linked to the levels of energy expenditure and body mass (for example, see Friedman \& Halaas, 1998; Friedman, 2000).

In fact, by looking much more closely at the patterns of variation in body mass over time, and their responses to interventions, the impression that energy balance is a regulated phenomenon, and that body mass plays a clear role in this regulation, is considerably strengthened. Take, for example, weekly records of body mass over a $6 \cdot 5$-year period (Fig. 1) for a single subject. During this time the subject made seven conscious interventions to reduce body mass. These interventions involved five energy-restricted diets, one period of exercise and one period of combined exercise and dieting. The interventions varied in duration from 2 months to 7 months and in all these cases the interventions produced substantial weight loss. In the most dramatic case body mass was reduced by about $20 \%$ over a period of 7 months of energy restriction. However, in all cases when the period of intervention had finished body mass increased again. An obvious interpretation of these changes is that body mass is regulated at about a level of $71 \mathrm{~kg}$. Interventions that take the subject below this critical limit result in a return towards this regulated level once the intervention is over. It appears that $71 \mathrm{~kg}$ is a target or 'set-point' around which mass is regulated in this subject.

The pattern of changes in body mass of this subject is not unusual. Over short periods energy intake and expenditure are often out of balance, resulting in changes in our body mass (Elia, 1992a), in contrast with the much longer-term balance between intake and expenditure (Friedman, 2000). Dietary interventions based on energy restriction are well established to be effective mechanisms for reducing body mass. However, once the dietary intervention has ended a large percentage of subjects, often 80-95, return to their original body mass (Garrow, 1988; Weintraub, 1992; Wadden, 1993). Similar compensatory responses to over-feeding are also widely observed (Bouchard et al. 1990).

The apparent stability of body mass over protracted periods and its resilience to change, in the context of the apparent ease with which massive changes in body mass could be effected, led to the idea that there is a 'lipostatic' system of food intake and energy expenditure regulation which sustains our body mass at a fixed and regulated level (Kennedy, 1953). The lipostatic model suggests that our body produces a signal that indicates how much fat we are carrying. The signal is read by the brain and compared with the target level at which that system is regulating body fatness. Changes are then effected in the levels of food intake and energy expenditure to either burn off excess energy if the body is over the target, or to eat more and expend less thereby accumulating fat if the body is below target. Our bodies are clearly not only composed of adipose tissue, and it was not long before other authors suggested that similar regulatory systems exist controlling, for example, our body protein content (Mellinkoff et al. 1956).

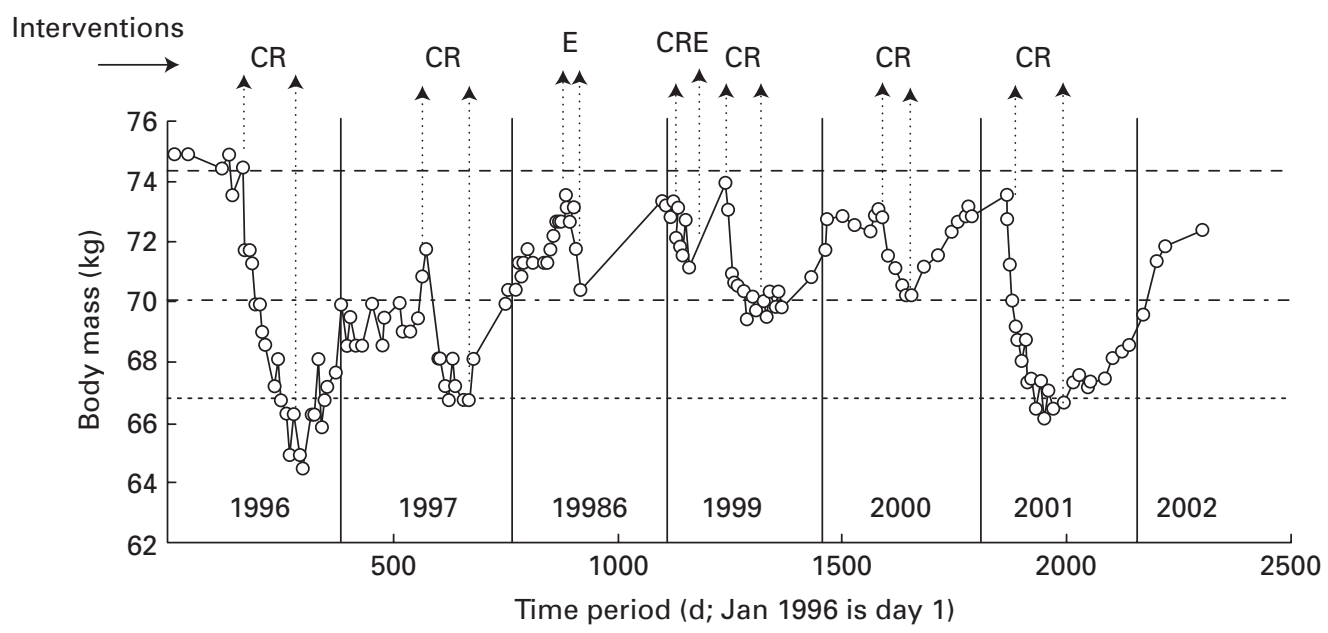

Fig. 1. Patterns of variation in body mass of a single male subject measured almost weekly over a period of $6 \cdot 5$ years. During this time period the subject engaged in seven interventions aiming to reduce body mass, which included five periods of energy restriction (CR), one period of exercise $(E)$ and one period of combined energy restriction and exercise (CRE). In all cases at the cessation of the intervention body mass increased again towards the pre-intervention levels. (-- -), BMI $25 \mathrm{~kg} / \mathrm{m}^{2} ;(-\cdot-)$, BMI $23 \cdot 4 \mathrm{~kg} / \mathrm{m}^{2} ;(\cdots), \mathrm{BMI} 22 \cdot 4 \mathrm{~kg} / \mathrm{m}^{2}$. 
Whether we have multiple regulatory systems, or only a single system that controls the primary levels of a single body component and partitioning of resources between compartments, is uncertain. Most recent treatments of the role of body mass in the regulation of food intake have tended to blur the distinction between body fat and total body mass (for example, see Campfield et al. 1997; Friedman \& Halaas, 1998; Friedman, 2000).

Studies of whole-animal energy balance in animal models have reinforced the view that body mass or fatness is regulated by a lipostatic signalling mechanism. In laboratory rodents the recovery response following experimentallyinduced changes in body mass is readily apparent, with animals returning to a level that is appropriate for their age, stage of development and/or environment after an imposed perturbation. Hence, rats subjected to a period of food deprivation or restriction, or to imposed overfeeding, express a compensatory hyper- or hypophagia on return to ad libitum feeding until they return to a body mass that is similar to that of controls feeding freely throughout (Keesey \& Hirvonen, 1997). Clearly, these compensatory responses are activated to 'defend' body mass at its existing level, or to restore it to that level once conditions allow. This ability to defend body mass or body composition against energy imbalance by induction of compensatory mechanisms is clear evidence of regulatory capability. This phenomenon suggests that there is central encoding of a 'target' body mass.

There is further experimental evidence that programmed adjustments can be made to the level of body mass that will be defended. The cycles of body mass and composition exhibited by seasonal mammals (Mercer, 1998; Morgan \& Mercer, 2001) are a particularly good example. These cycles are often cued from a single environmental variable (photoperiod) and have evolved as part of a battery of adaptations that enhance survival during winter in temperate and arctic latitudes (Mercer, 1998). The ability to programme changes in body mass and composition appears, therefore, to be superimposed on the capacity to defend an appropriate body mass against energy deficit or excess. These different levels of regulation are well illustrated by the seasonal Siberian hamster. Adult male hamsters reduce their body mass by approximately $30 \%$ following transfer from a summer-like long-day photoperiod to a winter-like shortday photoperiod. Limiting the supply of food during short days accelerates the rate at which mass is lost. When food restriction is lifted body mass increases, but only to the point where it approximates to the declining mass of control animals provided with unlimited food throughout. The rebound in body mass is driven by a period of hyperphagia (Mercer et al. 2001). During this period the animals actually increase in body mass. The system, therefore, behaves in a manner consistent with a seasonal timekeeping mechanism, continuing to adjust the encoded target body mass, even when animals are prevented from maintaining this desired body mass. These animals are apparently able to continually adjust the body mass that will be defended according to their photoperiodic history. Food restriction superimposed on the mass reduction in seasonal mammals (first reported in the hamster about 20 years ago; Steinlechner et al. 1983) provides some of the best evidence that mammals directly regulate their body mass.

\section{A physiological perspective}

Following modification of the stereotactic frame for use in the rat (Clark, 1939), many studies were carried out which involved lesioning different areas of the brains of small rodents and examining the consequences of such lesions for behaviour, to try to piece together the functional anatomy of the brain. In a now classic experiment Hethrington \& Ranson $(1940,1942)$ found that destruction of the ventromedial hypothalamus resulted in a hyperphagic syndrome where the rats became enormously obese. In contrast, electrically stimulating the same area resulted in a suppression of food intake (Margules \& Olds, 1962). This finding led to the notion that the ventromedial hypothalamus might be a 'satiety' centre responsible for inhibiting feeding, and that knocking it out resulted in the abolition of such inhibition. In contrast, lesions in the lateral hypothalamus (LH) had the opposite effect (Annand \& Brobeck, 1951), to the extent that some animals lesioned in this way may starve to death if not tube-fed. Moreover, electrical stimulation of the LH generally stimulates feeding (Andersson \& Wyrwicka, 1957). Consequently, feeding behaviour was suggested to reflect the interplay of activity in the LH switching feeding on, and activity in the ventromedial hypothalamus switching it off. Interestingly, animals with LH lesions that do recover some feeding behaviour following surgery do not adjust their body masses to the same levels as control animals, but regulate them at a lower level (Powley \& Keesey, 1970), leading these authors to suggest that the LH not only contains the feeding on-set centre, but that it is also the seat of the body mass set-point. As work developed in this area, attempting to tie down the effects to smaller and smaller areas of the hypothalamus, the crude nature of the original lesioning studies became apparent. It was clear that the simple satiety, feeding and body-mass regulation centres located in the ventromedial hypothalamus and LH respectively were an artefact of lesioning not only these areas but adjacent regions, and in particular damage to fibres passing adjacent to the lesioned areas (Hoebel \& Teitelbaum, 1966). Hence, while the hypothalamus seemed to be important for regulation of feeding behaviour, the precise locations of the key control nuclei was not made apparent by these studies.

Although physical lesioning studies in the brain had proved unable to resolve the precise location of control centres for feeding behaviour, increasing numbers of animals with genetic lesions were being produced by the major mouse and rat breeding centres in the USA and Europe. Perhaps the most famous of these mutant mice were the obese $(o b / o b)$ and the diabetic $(D b / D b)$ mice produced by the Jackson Laboratories (Bar Harbor, ME, USA), both of which had recessive Mendelian inherited mutations suggestive of single gene defects (Coleman, 1978). Homozygous recessives for both these mouse strains eat voraciously from birth, and by 12 weeks of age weigh about twice their heterozygous and homozygous dominant littermates.

In the late 1960s and early 1970s a series of elegant experiments were carried out on the $o b / o b$ and $D b / D b$ mice to try to elucidate the nature of the genetic defects they harboured (Coleman, 1973). These parabiosis experiments 
involved surgically operating on pairs of mice to join together their blood systems. Hence, any circulating factor in the blood of one animal would be passed to the other and vice versa. When the fat $o b / o b$ mouse was joined together in parabiosis with a lean wild-type mouse, the $o b / o b$ mouse started to eat less food and to lose body mass. However, when a fat $D b / D b$ mouse was joined in parabiosis to a lean wild-type mouse something radically different happened. The $D b / D b$ mouse was unaffected, but the wild-type mouse started to eat less food and eventually it died of starvation. Joining together $o b / o b$ and $D b / D b$ mice had a similar result to joining up $o b / o b$ mice to lean wild-type mice. The $o b / o b$ mouse reduced its food intake and started to lose mass, but the $\mathrm{Db} / \mathrm{Db}$ mouse continued eating and remained fat (Coleman, 1973).

These experiments provided strong support for the lipostatic body-weight-regulation model (Kennedy, 1953). It was clear that the $o b / o b$ mouse had a defect in the signal telling it how fat it was. In the absence of this signal the mice 'think' they are dangerously thin relative to their target and, therefore, elevate their food intake and suppress their metabolism and body temperature (Maffei et al. 1995), so that their body mass increases to meet the target. In parabiosis with wild-type mice they start to get a signal from the fat in the body of the lean mouse, and they suppress their food intake and normalise their body temperatures. Since this response also occurs when $o b / o b$ mice are in parabiosis with $D b / D b$ mice, the $D b / D b$ mutation cannot also be a problem with the signal. The mutation in $D b / D b$ mice must actually be a problem with reading the signal in the brain. Hence, they also 'think' they are dangerously thin and effect changes in their food intake and expenditure to bring their fatness up to target. When they are placed in parabiosis with wild-type mice there is no effect on their food intake because they are already producing lots of the signalling factor from their adipose tissue; it just is not being read, so getting more signal from the wild-type mouse has no effect. However, for the wild-type mouse it is more devastating, because in parabiosis with $D b / D b$ it gets a massive signal from the fat stores of the $D b / D b$ animal and, thinking it is massively over target, it shuts down its food intake to try to lose weight. As the $D b / D b$ partner keeps eating, however, there is always a signal telling the wild-type mouse not to eat, and eventually it dies of starvation.

\section{A molecular biology perspective}

Late in 1994 the mutation causing the $o b / o b$ mouse was found to be a single base mutation in a gene located on chromosome 6 of the mouse, and mapped to chromosome 7 of man (Zhang et al. 1994). The consequence of this mutation was that, instead of the gene signalling the production of a full-length 167-amino acid protein, there was a premature stop codon and a much shorter nonfunctional protein was produced. The intact protein was called 'leptin' from the Greek root leptos meaning 'thin', as the animals that had full-length leptin were lean. Leptin was shown to be produced exclusively in adipose tissue (Zhang et al. 1994), as might be anticipated to be the case for a compound that acted as a lipostatic signal of the size of body fat stores (subsequent work has shown other sites of production, at much lower levels, in developing foetuses, the placenta and the stomach). Recombinant leptin when injected into the ob/ob mouse caused the animals to dramatically decline in body mass (Halaas et al. 1995; Pelleymounter et al. 1995; Weigle et al. 1995; Friedman \& Halaas, 1998) and normalised many other features of the genetic pathology, including the ability to sexually mature and breed (Chehab et al. 1996). Perhaps of even greater interest was the fact that wild-type mice injected with leptin also reduced their body weight, as it might be expected that they would if they were receiving an erroneous signal about the size of their body fat stores (Halaas et al. 1995).

The leptin receptor (Tartaglia et al. 1995) is a class 1 cytokine receptor that exists as several splice variants. The long form of the receptor contains an intracellular signalling domain that is missing from the short form. Receptor localisation studies have revealed that the long form of the leptin receptor is found in large quantities in the arcuate nucleus of the hypothalamus (Mercer et al. 1996c). Energy balance-related circuits within the central nervous system involve both bioamines and neuropeptides and their respective receptors. Lately, most attention has been focused on the neuropeptide systems, with their function and regulation in a number of key hypothalamic nuclei being a specific focus for many research groups. The hypothalamic neuropeptides that are concerned with energy homeostasis can be divided into two categories (Schwartz et al. 2000). These categories are: (1) orexigenic, or anabolic, peptides such as neuropeptide Y (NPY) and agouti-related peptide (AGRP; Ollmann et al. 1997), which increase food intake, reduce energy expenditure and give rise to positive energy balance and weight gain when injected into the brain; (2) anorexigenic, or catabolic, peptides such as $\alpha$-melanocyte-stimulating hormone $(\alpha-\mathrm{MSH})$ and cocaine- and amphetamine-regulated transcript (CART; Kristensen et al. 1998), that have the opposite effect on each side of the energy-balance equation, leading to negative energy balance. Repeated administration of NPY, for example, leads to elevated food intake and increased body mass (Stanley et al. 1986), whereas NPY and AGRP mRNA are massively up regulated under conditions of imposed negative energy balance and reduced body mass (Schwartz et al. 1993; Mizuno \& Mobbs, 1999). These changes may underpin the return to 'normal' body mass when the energy restriction is lifted.

Since the landmark cloning of the leptin gene, new candidate energy balance-related genes have been emerging at a rate of several per year. Some of these signalling systems, such as the orexins (de Lecca et al. 1998; Sakurai et al. 1998), were previously unknown. In other cases peptides with well-established activity in other physiological systems, such as glucagon-like peptide-1 (Turton et al. 1996) or melanin-concentrating hormone (Qu et al. 1996), have also been demonstrated to affect energy homeostasis. It is now apparent that a major target for leptin feedback into the hypothalamic energy balance circuitry is the hypothalamic arcuate nucleus (Mercer et al. 1996a). Within the arcuate nucleus there are discrete populations of neurones, one of which expresses both the anabolic peptides NPY and AGRP (Broberger et al. 1998; Hahn et al. 1998; Chen et al. 1999), 
while another expresses the catabolic genes CART and proopiomelanocortin (Elias et al. 1998), the latter being translated into the pro-opiomelanocortin precursor that is subsequently processed to form $\alpha$-MSH. Gene expression of NPY increases when body fat declines (Kalra et al. 1991) and is stimulated in the $o b / o b$ mouse lacking leptin (Wilding et al. 1993), while transgenic knockout of NPY results in attenuation of the obese phenotype in the ob/ob mouse (Erickson et al. 1997). The interaction of leptin with NPY and other neuropeptide systems is almost certainly direct, since both NPY-AGRP and pro-opiomelanocortin-CART neurones in the arcuate nucleus also express the long-form leptin receptor mRNA (Mercer et al. 1996b; Cheung et al. 1997). $\alpha$-MSH and AGRP are components of the melanocortin system that culminates at the hypothalamic melanocortin receptors; the activity of $\alpha-\mathrm{MSH}$ at the melanocortin-4 receptor and the melanocortin-3 receptor is antagonised by AGRP (Ollmann et al. 1997; Gantz et al. 1999).

The importance of the leptin-melanocortin pathway in the maintenance of a normal body weight is emphasised by the clustering of morbidly-obese rodent strains around this pathway (Bultman et al. 1992; Miller et al. 1993; Zhang et al. 1994; Tartaglia et al. 1995; Yaswen et al. 1999), as the consequence of either spontaneous mutation or targeted transgenic manipulation. That these genes are also critical to regulation of body mass in human subjects is demonstrated by the occurrence of similar loss of function mutations to the leptin (Montague et al. 1997; Farooqi et al. 1998), leptin receptor (Clement et al. 1998), pro-opiomelanocortin (Krude et al. 1998) and melanocortin-4 receptor genes (Hinney et al. 1998; Vaisse et al. 1998; Yeo et al. 1998) in the human population that all result in severe obesity.

\section{The lipostatic consensus}

The lipostatic theory of body fatness-mass regulation has become the most widely-accepted model for the regulation of body fatness and thus body mass (Zhang et al. 1994; Leibel et al. 1995a; Collins et al. 1996; Hamann \& Matthaei, 1996; Campfield et al. 1997; Keesey \& Hirvonen, 1997; Satoh et al. 1997; Schwartz, 1997; Woods et al. 1997, 1998; Friedman \& Halaas, 1998; Levin \& Keesey, 1998; Friedman, 2000; Hirvonen \& Keesey, 2000; Schwartz et al. 2000). The lipostatic model suggests that fat produces leptin, which travels to the brain as a signal of how fat we are. In the brain this leptin signal is received by the long form of the leptin receptor in the hypothalamus, which then signals a whole series of downstream events that includes a system permitting comparison of the actual level of body fatness with a target level and then effects changes in food intake and energy expenditure via the NPY, CART, melanocortin and other systems in the brain, and the sympathetic system in the periphery, to bring about changes that regulate body fatness and mass.

As long ago as the 1950s it was recognised that our shortterm feeding behaviour is regulated by a different set of signals from those suggested to be involved in longer-term mass regulation (e.g. the glucostatic theory of Mayer (1955) and the satiety factors of Gibbs et al. (1973)). Even when our fat levels are under target and our leptin levels are lowered we do not feed continuously. Our feeding still occurs in discrete meals. A whole different set of signals turn our feeding behaviour on and off on a regular basis, generating this meal-based eating pattern. Signals transmitted in this way include the familiar meal-termination signal of gastric distension, which involves changes in the firing rate of the afferent vagus nerve (Schwartz, 2000) or blood concentrations of metabolites such as glucose, insulin, ghrelin (Horvath et al. 2001; Levin, 2002) and cholecystokinin (Gibbs et al. 1973; Moran, 2000). Some peripheral signals that are represented in the systemic bloodstream are able to interact directly with the central nervous system (Schwartz et al. 2000). These signals include glucose, insulin and glucocorticoids (Baskin et al. 1988; Levin, 2002), receptors which co-localise in areas where the long form of the leptin receptor is also found (e.g. the brain stem; Mercer et al. 1998). Moreover, insulin has been shown to have direct peripheral effect on leptin gene expression (Mueller et al. 1998; Wang et al. 1998). There is consequently a dynamic interplay between the long-term and short-term regulatory systems both peripherally and centrally (Havel et al. 1998; Wang et al. 1998; Schwartz et al. 2000). The immediate impetus to eat, and satiety, appear to be under the control of one regulatory system, and the whole longer-term balance is orchestrated by the 'lipostatic' system based on leptin (Woods et al. 1997, 1998; Schwartz et al. 2000).

\section{A perspective of the cause of obesity under the lipostatic model}

In the same environment different individuals sustain different body masses. According to the lipostatic model of food intake regulation obesity may have developed in some sub-populations of the obese primarily because these individuals have genetic defects in their lipostatic regulation systems. The role of genetics in the development of obesity has been long established from twin studies (Bouchard et al. 1990; Price \& Gottesman, 1991; Vogler et al. 1995). Studies of the parent-offspring correlations of BMI in biological and adoptive relationships suggest between 50 and $90 \%$ of the variation in BMI is genetic (Maes et al. 1997; Barsh et al. 2000), supporting the 'disrupted lipostatic' view of the cause of obesity.

For example, the regulatory system may be completely broken. Gross errors of this type in the molecular framework of the lipostat have been described in several individuals (Montague et al. 1997; Clement et al. 1998, Krude et al. 1998), and while these events are generally extremely rare, several screening studies have indicated that about $3 \%$ of all morbid obesity can be traced to polymorphic variations in the melanocortin-4 receptor in the melanocortin system (Hinney et al. 1998; Vaisse et al. 1998; Yeo et al. 1998). Nevertheless, such single gene polymorphisms are rare and explain only a minority of the observed population of obese subjects.

An alternative explanation for the differential development of obesity across individuals is that the lipostatic system may be working correctly, and variation in body 
mass between subjects might reflect different set-points in their lipostatic control systems. Such a variance in set-points may interact with the environment in which different populations are located. Consequently, in some situations it might not matter where the set-point target is located, since the availability of food and the energy expenditure required to harvest it may be so great that the system is perpetually externally constrained to never reach the target (Barsh et al. 2000). In contrast, the same population living in a society where energy is readily available in very palatable forms, requiring virtually no expenditure of energy to gather it, may readily achieve their potential set-point body masses. Variations over time and individual susceptibility are thus viewed under this lipostatic control interpretation as a consequence of a gene-environment interaction (Barsh et al. 2000). The environmental component of this interaction may include a whole host of social and environmental factors. Although this interaction is theoretically possible it does raise the question of what evolutionary mechanism might have resulted in the setting of the set-points at such high levels.

Another potential explanation for individual variations in the extent of obesity is that in obese individuals the system has become refractory to the peripheral leptin signal, socalled leptin resistance (Frederich et al. 1995; Friedman, 2000; Schwartz et al. 2000). The body fat produces sufficient leptin to act as a true signal of body mass, but for some reason, perhaps related to transport across the bloodbrain barrier (Frederich et al. 1995; Schwartz et al. 1996), or alterations in downstream sensitivity to the signal in the brain, this circulating leptin is not perceived by the brain, and the lipostatic system reads the low leptin level as indicative of a low body mass (below the target). This condition drives into action compensatory increases in food intake and reductions in expenditure, leading to obesity. The development of leptin resistance may also underpin the well-documented changes in prevalence of obesity with age (Ahren et al. 1997). As we get older on average we get fatter, and this change may be related to progressive leptin resistance, or a progressive shift in the lipostatic target body mass.

\section{Antithesis: the lipostat is an illusion of a much simpler system linking intake to immediate energy demands and historical energy balance}

Although the lipostatic model of body fatness-mass regulation enjoys widespread contemporary support, particularly among molecular biologists (see earlier discussion, p. 476), the idea that there is a 'set-point' system regulating our energy balance has long been an issue of contention (Wirtshafter \& Davis, 1977; Garrow, 1988). However, even in these arguments opponents of the set-point theories still generally included in their alternative models of energy homeostasis a feedback signal linking intake and expenditure to body mass (for example, see Wirtshafter \& Davis, 1977; Garrow, 1988). The argument revolved around whether this feedback signal acted directly on intake and expenditure, or in reference to a set-point. The argument we develop here is somewhat different, in that we propose a model for energy balance that includes no signal from mass at all, but from which mass regulation appears as an emergent property.

\section{A whole-body perspective}

In the introduction to the lipostatic model we presented the notion that a subject in perfect energy balance would be stable in body mass over protracted time periods. In contrast, a second subject who was in all respects identical to the first, with the exception that the subject ate more energy (equivalent to one apple each day) would accumulate enormous obesity ( $55 \mathrm{~kg}$ extra body fat tissue) over 25 years of this trivial imbalance. This often repeated 'trivial imbalance' argument, however, is spurious because it makes several critical erroneous assumptions.

The first erroneous assumption is that the accumulating tissue will all be fat. Generally, we do not change only our fat mass under conditions of energy imbalance, but rather we alter both lean and fat tissue compartments (Forbes, 1987; Saltzman \& Roberts, 1995; Evans et al. 1999; van Aggel-Leijssen et al. 2001; Weinsier et al. 2001). The relative contribution of this mix of lean and fat tissue appears to depend on several factors, but across a wide range of conditions there is an approximate 76:24 split of energy into adipose tissue:lean tissue mass when body mass increases or decreases. Thus, it would appear that this process exacerbates the situation, because lean tissue has a much lower energy density, so the actual body mass accumulation would be greater than if the mass is all assumed to be stored as fat. For example, in the scenario outlined earlier (p. 473), eating an excess $200 \mathrm{~kJ} / \mathrm{d}$ would result in $1825 \mathrm{MJ}$ excess energy split into $1387 \mathrm{MJ}$ devoted to adipose tissue $(42 \mathrm{~kg})$ and $438 \mathrm{MJ}$ devoted to lean tissue, resulting in a further $98 \mathrm{~kg}$ increase in body mass (assuming lean tissue has an energy content of $4.7 \mathrm{~kJ} / \mathrm{g}$ ). The total increase is now $140 \mathrm{~kg}$ instead of $55 \mathrm{~kg}$ when all the energy was stored as fat.

This differential use of the energy becomes important, however, when we consider the second assumption, and that is that all the additional tissue is inert and contributes nothing to daily energy demands. This assumption is bound up with the first assumption, because it is often assumed (sometimes explicitly, but often only implicitly) that adipose tissue places no energy demands on a subject. For example, expressing energy expenditure on a lean tissue basis effectively assumes that all the expenditure occurs in that tissue, and by implication the remaining tissue is inert. If all the accumulated excess energy is devoted to fat tissue growth (assumption 1), linking this assumption to a second assumption that fat tissue is inert, leads to the third assumption that the accumulating tissue incurs no increased costs. Recognising that assumption 1 is erroneous inevitably leads us to re-evaluate assumption 3, because the accumulating lean tissue will have implications for energy demands. In fact, assumption 2 is also erroneous, because while lean tissue expends more energy than adipose tissue, adipose tissue is not completely inert.

The energy demands of adipose and lean tissues have been evaluated in several different ways, and the results of these different approaches do not closely correspond. Early estimates were derived from the metabolic demands of tissues in culture (Field et al. 1939; Krebs, 1950) and 
suggested that the energy demands of adipose tissue were substantially lower than those of lean tissue. This option accords with estimates based on the arterio-venous difference in $\mathrm{O}_{2}$ content of blood supplying adipose tissue depots in vivo. Yet, in animal studies where analyses of resting metabolic rate have been compared with individual variation in body composition, a clear difference between adipose tissue and lean tissue does not emerge (for example, see Johnson et al. 2001). There are problems, however, with both approaches. First, measurements of $\mathrm{O}_{2}$ consumption in vitro and arterio-venous differences ignore any effect that secretions from adipose tissue have on the energy metabolism of other tissues (an obvious example being leptin; Halaas et al. 1997). However, body components do not vary independently, and consequently using a multiple regression approach to tease apart the contribution of lean and adipose tissue to total resting metabolic rate is plagued by the problems of predictor covariance. A further problem is that the 'lean' body compartment does not have a homogenous composition and different 'lean' organs and tissues expend energy at different rates. Muscle, for example, expends energy at only about $2 \cdot 8 \times$ the rate of adipose tissue, yet the liver expends energy almost $90 \times$ faster (Elia, 1992a,b; Elia et al. 1998; Greenberg, 1999). Combining typical estimates of the sizes of different organs suggests that on average lean tissue expends energy at $7 \times$ the rate of adipose tissue (calculated using data in Greenberg, 1999).

Consequently if a subject eats one apple each day in excess of initial daily energy requirements the resultant change in body mass will cause an upward shift in energy demands. After a short period of time the energy demands of the increased tissue mass will balance the amount of energy in one apple, and no further increase in body mass will occur, because the intake and expenditure are back in balance. In fact, we can model much more precisely what would happen to body mass under the 'trivial imbalance' scenario, using some simple empirical rules about the composition of body-mass changes (split 76:24 by energy in favour of adipose tissue) and the energy demands of fat and lean tissue (lean tissue expending energy $7 \times$ greater than fat tissue). Using this model the consequences of eating one extra apple each day are that body mass would increase by about $1.4 \mathrm{~kg}$ over a period of 5 months and then remain stable, because this $1.4 \mathrm{~kg}$ would be expending the equivalent energy each day to that contained in one apple. Excessive obesity would not develop. In fact, to accumulate and sustain $55 \mathrm{~kg}$ extra body tissue over a period of 25 years a subject would need to eat not just one extra apple each day, but rather an extra $3.2 \mathrm{MJ}$ energy each day relative to the subject who stays at $70 \mathrm{~kg}$.

The simple consequence on energy demands of accumulating or disappearing tissue, under conditions of energy imbalance, provides a mechanism that limits our ability to accumulate or get rid of large amounts of body mass (Leibel et al. 1995b). We generally do not grow enormously fat because the consequences of trivial imbalances for body mass are actually trivial. Contrary to widespread opinion that trivial imbalances will do the job, more realistic models that incorporate more realistic assumptions about the balance of lean and fat accumulation, in addition to recognising that this tissue adds to energy demands, reveal that to accumulate and sustain enormous obesity, energy intake and expenditure need to be much more divergent than often presumed.

Although the simple model developed previously makes more realistic predictions about the impact of eating one extra apple each day, it still contains several important implicit assumptions in its construction that we now make explicit and then modify to make them more realistic. First, the model assumes that all energy expenditure is a consequence of changes in body mass and composition. An even more realistic model, however, would acknowledge that there are also components of energy expenditure that vary largely independently of body composition, such as the expenditure on physical (PA) and non-physical activity (NEAT). An important second assumption is that the levels of food intake and the expenditure resulting from PA and NEAT do not cross talk with one another. In other words, elevation of PA or NEAT is assumed not to stimulate appetite, and reductions in food intake are presumed not to cause compensatory modulations of activity (PA or NEAT). There is some evidence that both such levels of compensatory change in appetite and expenditure do occur (for review, see Tappy, 2003), although the extent of compensation is a matter of debate (JE Blundell, unpublished results).

We constructed a second model that adjusts for these latter two assumptions. The model was parameterised arbitrarily with the following assumptions. First, it was assumed that PA occurs for a fixed period of $30 \mathrm{~min}$ each day, while non-vigorous activity was assumed to occupy $4 \mathrm{~h}$ each day. Expenditure levels for PA were assumed to be $4 \times$ resting metabolic rate, and for NEAT were assumed to equal $1.5 \times$ resting metabolic rate each day. Estimates of the extent of cross talk between activity and appetite were included, assuming that during periods of energy deficit PA and NEAT decline in proportion to the extent of the deficit.

An additional assumption of both the preceding models is that there is no memory of energy deficits or surpluses from day-to-day. Animals and man, however, may retain a memory of past deficits in energy intake. A good example is that if an animal is completely starved for $24 \mathrm{~h}$ it retains a memory of this starvation the next day and increases its food intake (Schwartz, 1997). This effect is equivalent to compensatory hunger driven by the history of energy deficit. Conversely, if an animal experiences positive energy balance for $1 \mathrm{~d}$, it may experience negative hunger and appropriate down-regulation of intake the following day. A third model was therefore constructed to include a memory of the average energy deficit over a $30 \mathrm{~d}$ period, and modulate food intake upwards or downwards in ad libitum conditions accordingly. Again, the model was arbitrarily parameterised with the following assumptions. Accumulated energy deficits over the previous $30 \mathrm{~d}$ were used to modulate food intake in the opposite direction by one-tenth of the accumulated imbalance. Hence, if over the previous $30 \mathrm{~d}$ energy expenditure exceeded intake by $30 \mathrm{MJ}(1 \mathrm{MJ} / \mathrm{d})$, then on the first day following release from restriction food intake would be elevated by $30 / 10(3 \mathrm{MJ})$. The accumulated deficit over $30 \mathrm{~d}$ would then be $27 \mathrm{MJ}$ and intake on day 2 following release from constraint would then be elevated by 
$2 \cdot 7 \mathrm{MJ}$. It was assumed, however, that there was asymmetry in the response to energy surplus compared with energy deficit. In energy surplus the contribution of the energy gain contributed only one-tenth the effect of energy deficit to the perceived hunger. These three models do not include a lipostatic regulatory component at their core.

What do these three models predict about our responses to dietary interventions? We used the models to predict changes in food intake, energy expenditure and body mass over a period of $1000 \mathrm{~d}$, including a period of $100 \mathrm{~d}$ food restriction at $6 \mathrm{MJ} / \mathrm{d}$ between days 300 and 400 . The modelling reveals the following patterns of body mass, expenditure and food intake (Figs. 2,3 and 4). Over days 1-300 for all three models food intake is stable, at about $12 \mathrm{MJ} / \mathrm{d}$, and expenditure is also stable at this level, so body mass is stable because the subject is in energy balance. On day 300, however, food intake declines to $6 \mathrm{MJ} / \mathrm{d}$ because of an imposed restriction. Under all three model predictions body mass starts to fall because fat and lean tissue are used to fuel the energy deficit. Expenditure falls slightly because of the mass loss under model 1 (Fig. 1) and, because of compensatory adjustments in levels of PA and NEAT, it falls at a greater rate in both models 2 and 3 (Figs. 3 and 4). Over days $300-400$ there is a progressive decline in body mass, which starts to reach an asymptotic loss because the decline in mass results in falling energy expenditure. In models 2 and 3 the asymptote is reached faster, and the extent of mass loss is lower, because the deficit is further
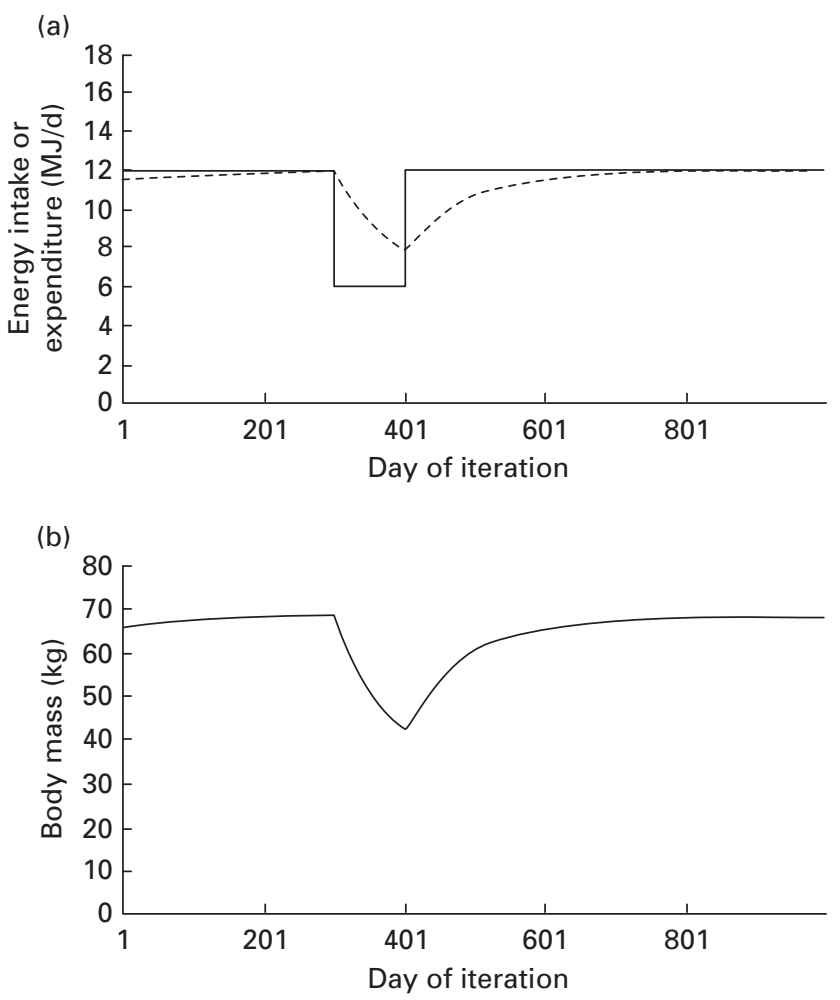

Fig. 2. Patterns of variation in (a) food intake (-) and energy expenditure (- - -) and (b) body mass, generated by a computer model founded on a model which assumes that energy deficits result in changes in both lean and fat tissue with consequent effects for resting energy expenditure. narrowed by the compensatory changes in PA and NEAT (compare Figs. 2,3 and 4).

In the third model hunger increases throughout the period of restriction and energy deficit, but then starts to fall as the time window over which the deficit generating 'hunger' starts to exclude the initial period where the deficit was at its greatest. A critical prediction from this model is that, ultimately, if the combined effects of weight loss and compensations in PA and NEAT match the level of externally-imposed energy intake for the duration of the time window that generates the hunger signal, there would be no 'hunger' modulating intake on release from restriction. In our example, over a $100 \mathrm{~d}$ period this state is not reached. Following release from restriction at day 100 , under model 3 'hunger' causes a post-restriction period of hyperphagia (Fig. 4). In models 1 and 2 after day 400 the subject returns to the original energy intake of $12 \mathrm{MJ} / \mathrm{d}$. During this phase in models 2 and 3 the compensations in PA and NEAT, driven by the previous energy deficit, unwind. In all three models, therefore, body mass starts to rise until ultimately the body mass before restriction is re-established, and a steady-state condition pertains that is equivalent to the starting condition. The three models differ in the speed at which the original state is attained; fastest in model 3 with the 'hunger' driven hyperphagia effect, and slowest in model 1 which lacks both the hunger and compensatory activity changes.
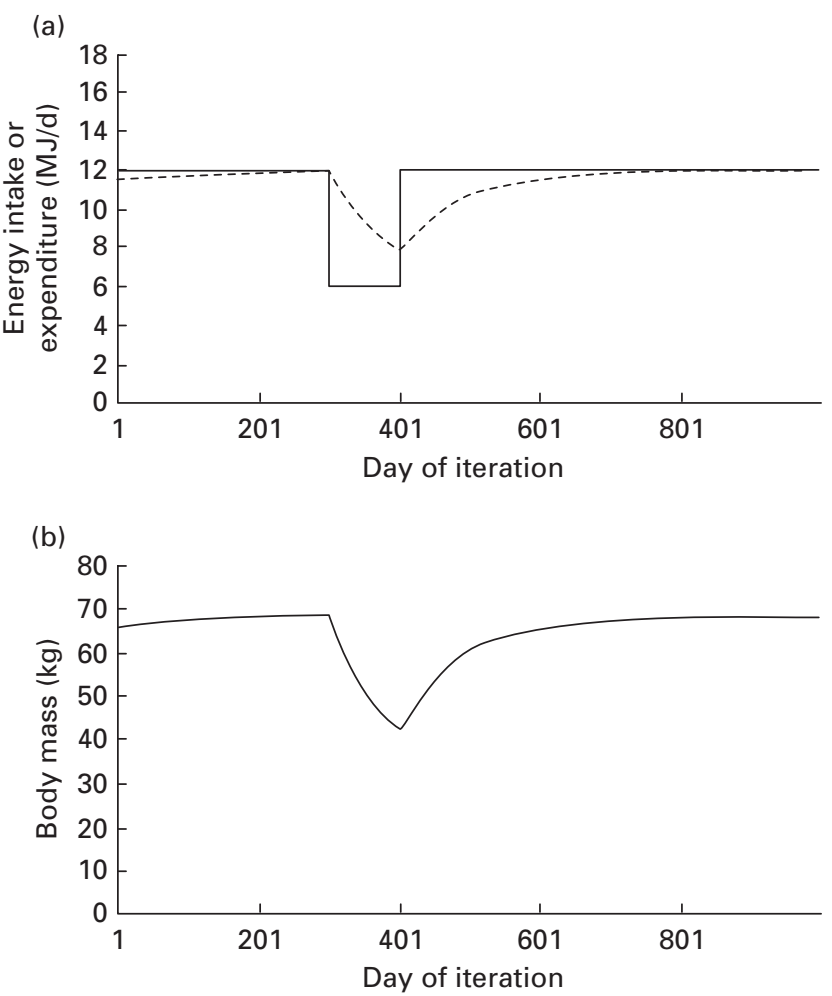

Fig. 3. Patterns of variation in (a) food intake (-) and energy expenditure (- - - ) and (b) body mass, generated by a computer model founded on a model which assumes that energy deficits result in changes in both fat and lean tissue with consequent effects for resting energy expenditure, and in addition energy deficits modulate negatively the levels of physical activity and non-physical activity thermogenesis. 

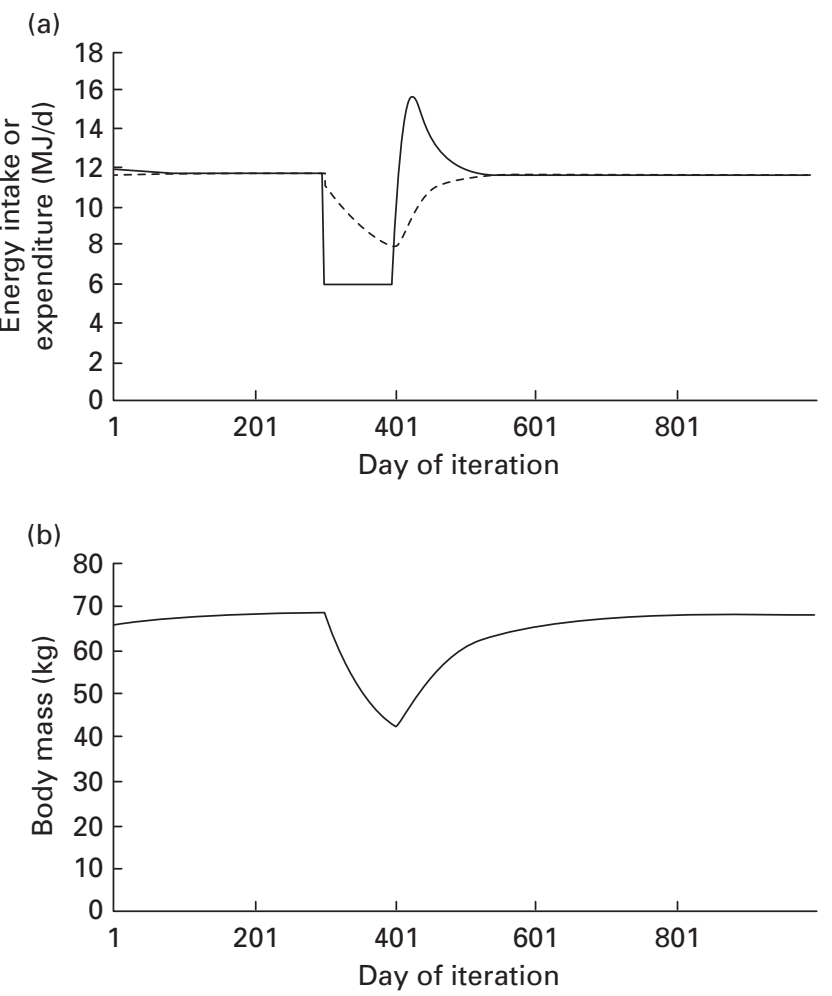

Fig. 4. Patterns of variation in (a) food intake (-) and energy expenditure (- - -) and (b) body mass, generated by a computer model which assumes the same as that in Fig. 3 , and in addition energy deficits accumulated over a memory time window of $30 \mathrm{~d}$ modulate food intake (upwards, when not externally restricted).

These three models include no component that signals the status of body mass, and yet they predict almost exactly the patterns of change in body mass that are observed in real subjects (compare changes in body mass in Figs. 1-4) and are widely believed to signal the existence of 'lipostatic' regulation, i.e. post-restriction increases in body mass to pre-restriction levels. In the third model these increases are also driven by the widely observed post-restriction hyperphagia.

Although the exact patterns revealed by these models depend on the exact parameterisation that is employed, the overall nature of the changes remains robust to the details of the parameterisation. Hence, changing the level of PA alters the point at which energy balance is achieved, and thus the equilibrium body mass, but not the fact that an equilibrium in mass occurs. The purpose of this modelling is not to dismiss the lipostatic model of body-mass regulation. Rather, our aim is to highlight the fact that observed variations in body mass, during and following periods of imbalance imposed by restriction, or overindulgence, can be explained by other models that do not invoke the existence of a lipostat. We are not reiterating the previous arguments about whether or not there is a set-point in the system to which a feedback signal is compared (Garrow, 1988), rather these models question the existence of any feedback signal at all from body mass. The key point that is often missed when interpreting the pattern of mass regain following a period of dietary restriction is that the subjects normally return to their original food intake and activity habits. Ultimately, these habits are compatible with only a single steady-state body mass. The fact that the manipulated mass immediately following release from manipulation returns to the original mass does not imply the existence of a lipostat, only the existence of a common intake and expenditure state before and following the period of restriction. The most important aspects of these three models from an epidemiological view (relating to the causes of obesity) are the factors that set our habitual food intake and activity levels.

\section{A molecular biology perspective}

The core of the molecular aspect of the lipostatic model is the notion that leptin provides a lipostatic signal, faithfully reporting levels of body fatness to the brain (Campfield et al. 1995, 1997; Woods et al. 1997, 1998; Friedman \& Halaas, 1998; Friedman, 2000; Schwartz et al. 2000). The major evidence supporting this stance is that leptin is produced almost exclusively by white adipose tissue (Zhang et al. 1994), and hence the levels of circulating leptin are correlated with body fatness (Considine et al. 1996). Other sources of leptin in non-reproductive individuals, such as the gastric mucosa, do not contribute substantially to circulating leptin levels. There are, however, a number of other factors that undermine this role as a lipostatic signal. The first is that the relationship between leptin levels and body adiposity is extremely weak (Considine et al. 1996; Hickey et al. 1996; Lahlou et al. 1997; Adami et al. 1998; Campostano et al. 1998). This position appears, at least in part, to be a consequence of differential leptin production in different adipose tissue depots (Bennett et al. 1997; Bennett, 1998; Coppack et al. 1998; Montague et al. 1998; Russell et al. 1998). Some adipose tissue depots produce considerably more leptin than other depots, and the balance of production appears to vary between species and also between developmental stages. It is difficult to imagine how an overall representation of body fatness can be derived if the production rates of the signalling compound are different in different depots. This problem is further exacerbated by the fact that in some species substantial production of leptin occurs outside the white adipose tissue. The most notable example is the chicken (Gallus domesticus), where there is substantial leptin production in the liver (Cassy et al. 2001; Taouis et al. 2001). In this species leptin cannot provide a faithful signal of adiposity unless the liver production of leptin is regulated in some manner by adipose tissue depot size.

A third aspect of the role of leptin is its effects on energy expenditure. These effects have been an issue of some debate, because some studies have indicated that administration of exogenous leptin stimulates an increase in energy expenditure (Luheshi et al. 1999), supposedly mediated via interleukin 1. This response is exactly what might be anticipated for a lipostatic signal modulating both expenditure and intake in opposite directions to bring about bodymass homeostasis. However, several other studies have failed to elicit the same effect (Haalas et al. 1995; Doring et al. 1997, 1998; Speakman et al. 1999).

Finally, leptin production appears to be extremely sensitive to the immediately preceding food intake or energy 
expenditure (Kolaczynski et al. 1996; Miyawaki et al. 1997; Li et al. 1998). There is a diurnal cycle in leptin production that, in human subjects, peaks during the night following food intake during the preceding day. This peak is driven almost exclusively by the pattern of food intake (Vinten et al. 1996; Schoeller et al. 1997; Tasaka et al. 1997), although some studies have indicated that there is also an endogenous component. The most important effect, however, is that when there is no food intake leptin remains depressed (Schoeller et al. 1997). This direct effect of the absence of food intake suppressing leptin production occurs before there is any noticeable effect on the magnitude of the size of fat stores, and clearly involves down-regulation of (or rather failure to up regulate) the levels of leptin gene expression. These latter changes strongly suggest that the dominant role of leptin is not as a peripheral lipostatic signal, but rather as a short-term starvation or energetic status signal, as strongly advocated by Flier and colleagues (Ahima et al. 1996). This approach is further supported by evidence that chronically-food-deprived patients with anorexia nervosa have disproportionately reduced leptin levels relative to their body fatness (Grinspoon et al. 1996; Hebebrand et al. 1997; Herpertz et al. 1997, 1998).

\section{A physiological perspective}

Having revised our interpretations of the existing molecular data, which indicate at least as much support for the alternative model as for the lipostatic model, we may also reinterpret what is happening in the mutant $o b / o b$ and $\mathrm{Db} / \mathrm{Db}$ mice and the parabiosis experiments (Coleman, 1973). In our previous interpretation we suggested that the gross obesity of the $o b / o b$ and $D b / D b$ mice is a consequence of them failing to sense how fat they are, because they are unable to produce or read (respectively) the leptin adiposity signal. They consequently 'think' they are dangerously thin, and effect hyperphagia and reductions in energy expenditure mechanisms to effect increases in body fatness and overall mass. The alternative interpretation of these observations is that the animals do not lack a signal telling them how fat they are, but rather they lack a signal telling them they have eaten food that day. They do not think they are dangerously thin, but rather they think they are in dangerous negative energy balance. Consequently, they activate compensatory mechanisms in their expenditure to reduce the impact of the energy imbalance, and also become hyperphagic to reverse the imbalance. Unfortunately, they never get the signal and sustain protracted positive energy balance leading to gross obesity.

An interesting observation of $o b / o b$ and $D b / D b$ mice that supports the starvation signal rather than the lipostatic signal interpretation is that they do not increase in body mass indefinitely, but instead reach an asymptote. Why does this happen? An interpretation under the lipostatic model is that there is an additional lipostatic signal indicating body fatness that is activated only at high levels of body fatness. This suggestion is interesting, but it is difficult to imagine how such a 'high-fatness' signal system might evolve in the presence of the low-fatness regulatory system, even ignoring the difficulty of imagining a function for such a 'high-fatness' regulation system. However, under the simple non-lipostatic models outlined earlier an asymptote is actually expected, because the absence of leptin is the ultimate starvation signal that generates a maximal food intake response. Inevitably, however, the resultant increases in body mass generated by the energy imbalance will elevate expenditure, and eventually at a level of morbid obesity the animal will be in energy balance, resulting in no further accumulation of body tissue.

\section{The simple non-lipostatic models: summary}

The non-lipostatic models highlighted earlier take as their fundamental starting point the fact that no body tissue is inert, and any changes in body mass include alterations in both lean and fat tissue compartments. Any imbalance between intake and expenditure results in tissue storage that itself narrows the difference in the imbalance because of elevated or decreased expenditure. In its simplest form the model includes only this effect. More refined versions of the simple model include first, compensatory changes in activity to immediate energy imbalance, and second, 'hunger' driven by a memory of past energy imbalance. These two additional factors modulate the speed at which body mass moves between states as food intake is modulated by external forces (such as imposed food restriction). The most-refined model predicts all the observed patterns of variation in body mass, post-restriction hyperphagia and modifications in expenditure that accompany imposed energy imbalances, without the need to invoke a lipostatic signalling system, as the underlying cause of these phenomena.

\section{Obesity and the non-lipostatic model}

In the non-lipostatic models we have assumed that the habitual food intake of the subject and the habitual levels of PA and NEAT are fixed traits that can be modulated by the subject's regulatory system under various conditions, but to which the subject returns under extended de-restriction. The balance of the magnitude of these 'habitual' traits in any given individual defines the eventual steady-state body mass and body fatness. The key question, therefore, for the interpretation of the causes of obesity under this pattern of energy regulation is: what are the factors that affect these salient traits? We suggest that these traits are likely to be the product of a whole range of factors, including genetic polymorphisms in the important signalling systems that indicate current and historical energetic status (such as leptin and the melanocortin system) and thus drive food intake and energy expenditure. However, in addition to genetic factors there are likely to be a whole host of nongenetic factors, including foetal programming effects, earlylife conditioning, social factors, peer pressure, education, poverty, social status and the immediate 'environment', all of which will impact on our 'lifestyles'. These factors are largely relegated in the 'lipostatic' interpretation to a minor role.

Under the 'non-lipostatic' model these other non-genetic factors assume a much greater importance. Hence, changes in the patterns of obesity over time are interpreted as a consequence of social changes in our lifestyles, including 
the spread of car ownership, social dining and TV viewing. Differences between individuals are bound up in the extent to which individuals assume different lifestyles. This factor may have a large genetic component (as is assumed in the lipostatic model, and suggested from the variance in BMI explained by genetics; Barsh et al. 2000), but there is also room in the 'non-lipostatic' models for a large impact of other 'social' factors as well. In the case of age-related changes in obesity, for example, the lipostatic model interprets these changes as resulting from progressive shifts in the set-point, or leptin resistance. However, in the nonlipostatic model these changes might be a result of developmental changes in the system signalling energetic status, but could equally reflect social changes in lifestyle (such as greater affluence and reduced PA), or other developmental physiological events such as the declining resting metabolic rate as a function of age (Greenberg, 1999). Moreover, some patterns in the epidemiology of obesity (e.g. the existence of substantially higher levels of obesity in groups of lower educational achievement and lower social class) can be easily interpreted under the non-lipostatic model (because of social and educational factors that impact on energy intake and expenditure that are unique to these groups). These patterns pose difficulties, however, for the pure 'lipostatic' model, unless we also presume lower social status and education correlates with a higher set-point in the lipostat or increased leptin resistance, or that these social factors can easily over-ride the lipostatic control system.

\section{Synthesis}

\section{Implications}

Interpretations of the molecular biological information depend on the models assumed to exist for regulation of food intake and energy balance. If it is assumed that there is a lipostatic regulatory system, developments in our understanding of the molecular basis of feeding will be interpreted within the lipostatic framework. Yet, this model is not the only explanation for the manner in which food intake and energy balance might be regulated. The molecular patterns presumed to underpin the lipostat may in fact underpin other regulatory systems.

This rather subtle difference in interpretation of the molecular data, however, has some important ramifications. The success of putative pharmacological and other manipulations aiming to treat obesity depend critically on the actual framework by which food intake and energy balance are regulated. Most current attempts to develop pharmacological treatments for obesity, and public health education initiatives, are aimed at modulating the rate of food intake, either by suppressing appetite or by affecting the absorption processes in the alimentary tract so that less energy is absorbed. Alternatively, many studies are directed towards the development of agents that will manipulate energy expenditure (Lowell \& Spiegelman, 2000).

Both the different models (lipostatic and non-lipostatic) indicate why these public health and pharmacological initiatives generally fail to be successful long-term solutions. Under the lipostatic model this failure is because the treatments only succeed in driving the system into a state where actual body mass is out of line with the lipostatic set-point. Hence, at the conclusion of treatment a return to the original body mass driven by hyperphagia, during the period immediately following release from constraint, is inevitable. In the non-lipostatic model prolonged dietary restriction in energy balance might avoid rebound hyperphagia, but on release from restriction a return to the habitual food intake and activity levels that were sustained before intervention will result in a return to the previous body mass and composition.

Under the non-lipostatic model the only successful solutions are likely to be those that cause permanent changes in the critical lifestyle variables. This process will require lifelong drug treatments, major social engineering or powerful behavioural therapies to overcome the impetus of the genetic factors that probably underpin these variables, leading to the high genetic component in the determination of obesity (Barsh et al. 2000). However, if body mass and condition are regulated by a lipostatic system, then there is an alternative solution, which is to determine and modify the physiological basis of the set-point in the system. Pharmaceutical modulation of the set-point will be considerably more effective than modulation of intake and expenditure, because the changes in food intake and expenditure to bring the actual and set-point levels into alignment will occur as downstream events to the manipulation, and at the end of the manipulation there will be no hyperphagic rebound response because actual and set-point body masses will be in balance. If a method of permanently resetting the lipostat set-point could be devised, then a permanent treatment might also be possible. Currently, however, there appears to be a fundamental mismatch in the modern consensus of how the system works (i.e. dominated by lipostatic models) and the strategies being developed to try to manipulate the system (direct manipulations of intake and expenditure by pharmaceutical or public health means).

Finally, it is important to recognise that we do not anticipate that all animals will conform to any single one of these interpretive models. It is likely that different species under different evolutionary scenarios will have evolved systems appropriate to their own circumstances. In some species these systems will be lipostatic systems, where body mass plays a role in the regulatory framework, but in other species the system may be regulated primarily nonlipostatically by energy deficits. A previous review (Mercer \& Speakman, 2001) highlighted why such differences in regulation might be anticipated, in particular between small and large animals. In small animals regulation of body mass (fatness) may be a key issue, because the scaling of energy demands to body mass combined with the scaling of potential fat storage to body mass means that these animals have little margin of error for survival during periods of low food supply. On the other hand, they will be commonly susceptible to predation that may also be mass dependent. In this situation we might anticipate evolution would favour a system allowing the regulation of body mass within strict bounds, aiming to avoid starvation and predation risks (i.e. a lipostat). In contrast large animals have much greater starvation tolerance, and are also less likely to be affected by mass-dependent predation risks. For these animals, having a strong input from body mass regulating energy balance 
seems less likely to evolve, and a system based on energy deficit might be more probable.

As we have pointed out previously, man is a large animal, but the animal models that we routinely employ to tease apart the molecular events underpinning the regulation of energy balance generally weigh two to three orders of magnitude less. Given the different evolutionary pressures in relation to body size this mismatch may be a serious problem hindering the development of a fuller understanding of the regulatory system in man. Since evolution has had to work with a phylogenetically-constrained substrate, the basic molecular framework underpinning the control of food intake in different species may be largely the same, but the details of the manner in which the systems operate may be subtly different. Establishing appropriate animal models that accurately mimic what is going on in man may therefore be crucial in the process of developing effective therapies.

\section{References}

Adami GF, Campostano A, Ravera G, Cella F \& Ligas B (1998) Relationship between body mass index and serum leptin concentration. Diabetes Nutrition and Metabolism 11, 17-19.

Ahima RS, Campostano A, Ravera G, Cella F \& Ligas B (1996) Role of leptin in the neuroendocrine response to fasting. Nature 382, 250-252.

Ahren B, Mansson S, Gingerich RL \& Havel PJ (1997) Regulation of plasma leptin in mice: Influence of age, high-fat diet, and fasting. American Journal of Physiology 42, R113-R120.

Andersson B \& Wyrwicka W (1957) The elicitation of a drinking motor conditioned reaction by electrical stimulation of the 'drinking area' in the goat. Acta Physiologica Scandinavica 41, 194-198.

Annand BK \& Brobeck JR (1951) Hypothalamic control of food intake in rats and cats. Yale Journal of Biology and Medicine 24, 123-140.

Barsh GS, Farooqi SI \& O'Rahilly S (2000) Genetics of bodyweight regulation. Nature 404, 644-651.

Baskin DG, Wilcox BJ, Figlewic DP \& Dorsa DM (1988) Insulin and insulin-like growth factors in the CNS. Trends in Neuroscience 11, 107-111.

Bennett FI (1998) Are serum leptin correlations influenced by fat placement? Reply. American Journal of Clinical Nutrition 68, 755-756.

Bennett FI, McFarlaneAnderson N, Wilks R, Luke A, Cooper RS \& Forrester TE (1997) Leptin concentration in women is influenced by regional distribution of adipose tissue. American Journal of Clinical Nutrition 66, 1340-1344.

Bouchard C, Tremblay A, Despres JP, Nadeau A, Lupien PJ, Theriault G, Dussault J, Moorjani S, Pinault S \& Fournier G (1990) The response to long term overfeeding in identical twins. New England Journal of Medicine 322, 1477-1482.

Broberger C, Johansen J, Johansson C, Schalling M \& Holiman S (1998) The neuropeptide Y/agouti gene-related protein (ACRP) brain circuitry in normal, anorectic, and monosodium glutamatetreated mice. Proceedings of the National Academy of Sciences USA 95, 15043-15048.

Bultman SJ, Michaud EJ \& Woychik RP (1992) Molecular characterization of the mouse agouti locus. Cell 71, 1204.

Campfield LA, Smith FJ \& Burn P (1997) OB protein: A hormonal controller of central neural networks mediating behavioral, metabolic and neuroendocrine responses. Endocrinology and Metabolism 4, 81-102.

Campfield LA, Smith FJ, Guisez Y, Devos R \& Burn P (1995) Recombinant mouse ob protein: evidence for a peripheral signal linking adiposity and central neural networks. Science 280, 546-549.

Campostano A, Grillo G, Bessarione D, De Grandi R \& Adami GF (1998) Relationships of serum leptin to body composition and resting energy expenditure. Hormone and Metabolic Research 30, 646-647.

Cassy S, Dridi S, Picard M \& Taouis M (2001) Leptin in chicken. Productions Animales 14, 161-169.

Chehab FE, Lim ME \& Lu RH (1996) Correction of the sterility defect in homozygous obese female mice by treatment with the human recombinant leptin. Nature Genetics 12, 318-320.

Chen P, Li C, Haskell-Luevano C, Cone RD \& Smith MS (1999) Altered expression of agouti-related protein and its colocalization with neuropeptide $\mathrm{Y}$ in the arcuate nucleus of the hypothalamus during lactation. Endocrinology 140, 2645-2650.

Cheung CC, Clifton DK \& Steiner RA (1997) Proopiomelanocortin neurons are direct targets for leptin in the hypothalamus. Endocrinology 138, 4489-4492.

Clark G (1939) The use of the Horsley-Clarke instrument on the rat. Science 90, 92.

Clement K, Vaisse C, Lahlou N, Cabrol S, Pelloux V, Cassato D, Gourmelen M, Dina C, Chambaz J, Lacorte JM, Basdevant A, Bougneres P, Lebouc Y, Froguel P \& Guy-Grand B (1998) A mutation in the human leptin receptor gene causes obesity and pituitary dysfunction. Nature 392, 398-401.

Coleman DL (1973) Effects of parabiosis of obese with diabetes and normal mice. Diabetologia 9, 294-298.

Coleman DL (1978) Obese and diabetes: Two mutant genes causing diabetes-obesity syndromes in mice. Diabetologia 14, 141-148.

Collins S, Kuhn CM, Petro AE, Swick AG, Chrunyk BA \& Surwit RS (1996) Role of leptin in fat regulation. Nature 380, 677.

Considine, RV, Sinha MK, Heiman ML, Kriauciunas A, Stephens TW, Nyce MR, Ohannesian JP, Marco CC, McKee LJ, Bauer TL \& Caro JF (1996) Serum immunoreactive leptin concentrations in normal-weight and obese humans. New England Journal of Medicine 334, 292-295.

Coppack SW, Pinkney JH \& Mohamed-Ali V (1998) Leptin production in human adipose tissue. Proceedings of the Nutrition Society 57, 461-470.

de Lecca L, Kilduff TS, Peyron C, Gao XB, Foye PE, Danielson PE, Fukuhara C, Battenberg ELF, Gautvik VT, Bartlett FS, Frankel WN, Van Den Pol AN, Bloom FE, Gautvik KM \& Sutcliffe JG (1998) The hypocretins: hypothalamus-specific peptides with neuroexcitatory activity. Proceedings of the National Academy of Sciences USA 95, 322-327.

Doring $\mathrm{H}$ et al. (1997) Leptin effects in free-feeding and food-restricted mice. Pflugers Archiv - European Journal of Physiology 433, 640.

Doring $\mathrm{H}$ et al. (1998) Leptin selectively increases energy expenditure of food-restricted lean mice. International Journal of Obesity 22, 83-88.

Elia M (1992a) Energy expenditure in the whole body. In Energy Metabolism: Tissue Determinants and Cellular Corollaries, pp. 19-60 [JM Kinney and HN Tucker, editors]. New York: Raven.

Elia M (1992b) Organ and tissue contributions to metabolic rate. In Energy Metabolism: Tissue Determinants and Cellular Corollaries, pp. 61-80 [JM Kinney and HN Tucker, editors]. New York: Raven.

Elia M, Stubbs RJ \& Henry CJK (1998) Differences in fat, carbohydrate and protein metabolism between lean and obese subjects undergoing total starvation. Obesity Research 76, 597-604. 
Elias CF, Lee C, Kelly J, Aschkenasi C, Ahima RS, Couceyro PR, Kuhar MJ, Saper CB \& Elmquist JK (1998) Leptin activates hypothalamic CART neurons projecting to the spinal cord. Neuron 21, 1385.

Erickson JC, Ahima RS, Hollopeter G, Flier JS \& Palmiter RD (1997) Endocrine function of neuropeptide Y knockout mice. Regulatory Peptides 70, 199-202.

Evans EM, Saunders MJ, Spano MA, Arngrimsson SA, Lewis RD \& Cureton KJ (1999) Body-composition changes with diet and exercise in obese women: a comparison of estimates from clinical methods and a 4-compartment model. American Journal of Clinical Nutrition 70, 5-12.

Farooqi S, Rau H, Whitehead J \& O'Rahilly S (1998) ob gene mutations and human obesity. Proceedings of the Nutrition Society 57, 471-475.

Field J, Belding HS \& Martin AW (1939) An analysis of the relation between basal metabolism and summated tissue respiromation in the rat. I. The post-pubertal albino rat. Journal of Cellular and Comparative Physiology 14, 143-157.

Forbes GB (1987) Human Body Composition. New York: Springer Verlag.

Frederich RC, Hamann A, Anderson S, Lollmann B, Lowell BB \& Flier JS (1995) Leptin levels reflect body lipid content in mice - evidence for diet induced resistance to leptin action. Nature Medicine 1, 1311-1314.

Friedman JM (2000) Obesity in the new millennium. Nature 404, $632-634$.

Friedman JM \& Halaas JL (1998) Leptin and the regulation of body weight in mammals. Nature 395, 763-770.

Gantz I, Bagnol D, Lu XY, Kaelin CB, Day HE, Ollman M, Gantz I, Akil H, Barsh GS \& Watson SJ (1999) Anatomy of an endogenous antagonist: relationship between Agouti-related protein and proopiomelanocortin in brain. Journal of Neuroscience 19, RC26.

Garrow JS (1988) Obesity and Related Diseases. London: Churchill Livingstone.

Gibbs J, Young RC \& Smith GP (1973) Cholecystokinin decreases food intake in rats. Journal of Comparative Physiology and Psychology 84, 488-495.

Greenberg JA (1999) Organ metabolic rates and aging: two hypotheses. Medical Hypotheses 52, 15-22.

Grinspoon S, Gulick T, Askari H, Landt M, Lee K, Anderson E, Ma ZM, Vignati L, Bowsher R, Herzog D \& Klibanski A (1996) Serum leptin levels in women with anorexia nervosa. Journal of Clinical Endocrinology and Metabolism 81, 3861-3863.

Hahn TM, Breininger JF, Baskin DG \& Schwartz MW (1998) Coexpression of Agrp and NPY in fasting-activated hypothalamic neurons. Nature Neuroscience 1, 271-272.

Halaas JC, Coajiwala KS, Maffei M, Cohen SL, Chait BT, Rabinowitz D, Lallone RL, Burley SK \& Friedmann JM (1995) Weight-reducing effects of the plasma protein encoded by the obese gene. Science 269, 543-546.

Halaas JL, Boozer C, BlairWest J, Fidahusein N, Denton DA \& Friedman JM (1997) Physiological response to long-term peripheral and central leptin infusion in lean and obese mice. Proceedings of the National Academy of Sciences USA 94, 8878-8883.

Hamann A \& Matthaei S (1996) Regulation of energy balance by leptin. Experimental and Clinical Endocrinology and Diabetes 104, 293-300.

Havel PJ, Stern JS \& Keim NL (1998) Circulating leptin concentrations are related to eating behavior, and to appetite during energy restriction in women. FASEB Journal 12, 1181.

Hebebrand J, Blum WF, Barth N, Coners H, Englaro P, Juul A, Ziegler A, Warnke A, Rascher W \& Remschmidt H (1997) Leptin levels in patients with anorexia nervosa are reduced in the acute stage and elevated upon short-term weight restoration. Molecular Psychiatry 2, 330-334.

Herpertz S, Wagner R, Albers N, Blum WF, Pelz B, Langkafel M, Kopp W, Henning A, Oberste-Berghaus C, Mann K, Senf W \& Hebebrand J (1998) Circadian plasma leptin levels in patients with anorexia nervosa: Relation to insulin and cortisol. Hormone Research 50, 197-204.

Herpertz S, Wagner R, Pelz B, Blum W, Hebebrand J, Mann K \& Senf W (1997) Disproportionally low serum leptin levels and abolition of nocturnal rise in patients with anorexia nervosa. Diabetes 46, 970.

Hethrington AW \& Ranson SW (1940) Hypothalamic lesions and adiposity in the rat. Anatomical Record 78, 149-161.

Hethrington AW \& Ranson SW (1942) The spontaneous activity and food intake of rats with hypothalamic lesions. American Journal of Physiology 136, 609-617.

Hickey MS, Considine RV, Israel RG, Mahar TL, McCammon MR, Tyndall GL, Houmard JA \& Caro JF (1996) Leptin is related to body fat content in male distance runners. American Journal of Physiology 34, E938-E940.

Hinney A, Becker I, Heibult O, Nottebom K, Schmidt A, Ziegler A, Mayer H, Siegfried W, Blum WF, Remschmidt H \& Hebebrand J (1998) Systematic mutation screening of the pro-opiomelanocortin gene: Identification of several genetic variants including three different insertions, one nonsense and two missense point mutations in probands of different weight extremes. Journal of Clinical Endocrinology and Metabolism 83, 3737-3741.

Hirvonen MD \& Keesey RE (2000) The regulation of body weight: set-points and obesity. Handbook of Experimental Pharmacology 149, 133-151.

Hoebel BG \& Teitelbaum P (1966) Weight regulation in normal and hypothalamic hyperphagic rats. Journal of Comparative Physiology and Psychology 61, 189-193.

Horvath TL, Diano S, Sotonyi P, Heiman M \& Tschop M (2001) Minireview: ghrelin and the regulation of energy balance - a hypothalamic perspective. Endocrinology 142, 4163-6169.

Johnson MS, Thomson SC \& Speakman JR (2001) Limits to sustained energy intake. II. Inter-relationships between resting metabolic rate, life-history traits and morphology in Mus musculus. Journal of Experimental Biology 204, 1937-1946.

Kalra SP, Dube MG, Sahu A, Phelps CP \& Kalra P (1991) Neuropeptide $\mathrm{Y}$ secretion increases in the paraventricular nucleus in association with increased appetite for food. Proceedings of the National Academy of Sciences USA 88, 10931-10935.

Keesey RE \& Hirvonen MD (1997) Body weight set-points: determination and adjustment. Journal of Nutrition 127, 1875S-1883S.

Kennedy GC (1953) The role of depot fat in the hypothalamic control of food intake in the rat. Proceedings of the Royal Society of London 140B, 578-592.

Kolaczynski JW, Considine RV, Ohannesian JP, Marco CC, Nyce MR, Opentanova I, Sinha MK, Zhang PL \& Caro JF (1996) Responses of leptin to fasting and refeeding in man: Evidence for dual mechanism of regulation of circulating leptin levels. Diabetes 45, 145.

Krebs HA (1950) Body size and tissue respiration. Biochimica et Biophysica acta 4, 269.

Kristensen P, Judge ME, Thim U, Ribel U, Christjansen KN, Wulff BS, Clausen JT, Jense PB, Madsen OD, Vrang N, Larsen PJ \& Hastrup S (1998) Hypothalamic CART is a new anorectic peptide regulated by leptin. Nature 393, 72-76.

Krude H, Biebermann H, Luck W, Horn R, Brabant G \& Gruters A (1998) Severe early-onset obesity, adrenal insufficiency and red hair pigmentation caused by POMC mutations in humans. Nature Genetics 19, 155-157. 
Lahlou N, Landais P, DeBoissieu D \& Bougneres PF (1997) Circulating leptin in normal children and during the dynamic phase of juvenile obesity - Relation to body fatness, energy metabolism, caloric intake, and sexual dimorphism. Diabetes $\mathbf{4 6}$, 989-993.

Leibel R, Rosenbaum M \& Hirsch J (1995a) Changes in energy expenditure resulting from altered body weight. New England Journal of Medicine 332, 621.

Leibel RL, Rosenbaum M \& Hirsch J (1995b) Changes in energy expenditure resulting from altered bodyweight. New England Journal of Medicine 332, 621-628.

Levin BE (2002) Metabolic sensors: viewing glucose sensing neurons from a broader perspective. Physiology and Behavior 76, 397-401.

Levin BE \& Keesey RE (1998) Defense of differing body weight set-points in diet-induced obese and resistant rats. American Journal of Physiology 274, R412-R419.

Li H, Matheny M, Tumer N \& Scarpace PJ (1998) Effects of aging and fasting on the regulation of leptin gene expression and hypothalamic neuropeptide Y gene expression. FASEB Journal 12, 3209.

Lowell BB \& Spiegelman BM (2000) Towards a molecular understanding of adaptive thermogenesis. Nature 404, 652-660.

Luheshi GN, Gardner JD, Rushforth DA, Loudon AS \& Rothwell NJ (1999) Leptin actions on food intake and body temperature are mediated by IL-1. Proceedings of the National Academy of Sciences USA 96, 7047-7052.

Maes HH, Neale MC \& Eaves LJ (1997) Genetic and environmental factors in relative body weight and human adiposity. Behavior Genetics 27, 325-351.

Maffei M, Halaas J, Ravussin E, Pratley RE, Lee GH, Zhang Y, Fei H, Kim S, Lallone R, Ranganathan S, Kern PA \& Friedman JM (1995) Leptin levels on human and rodent - measurement of plasma leptin and $\mathrm{Ob}$ RNA in obese and weight reduced subjects. Nature Medicine 1, 1155-1161.

Margules DL \& Olds J (1962) Identical 'feeding' and 'rewarding' systems in the lateral hypothalamus of rats. Science 135, 374-375.

Mayer A (1955) Regulation of energy intake and body weight: the glucostatic theory and the lipostatic hypothesis. Annals of the New York Academy of Science 63, 15-42.

Mellinkoff S, Franklin M, Boyle D \& Geipell G (1956) Relationship between serum amino acid concentration and fluctuation in appetite. Journal of Applied Physiology 8, 535-538.

Mercer JG (1998) Regulation of appetite and body weight in seasonal mammals. Comparative Biochemistry and Physiology 119C, 295-303.

Mercer JG, Hoggard N, Lawrence CB, Rayner DV \& Trayhurn P (1996a) Localization of leptin receptor (OB-R) gene expression in mouse brain by in situ hybridization. Journal of Physiology 495, $113 \mathrm{P}$.

Mercer JG, Hoggard N, Williams LM, Lawrence CB, Hannah LT, Morgan PJ \& Trayhurn P (1996b) Coexpression of leptin receptor and preproneuropeptide $\mathrm{Y}$ mRNA in arcuate nucleus of mouse hypothalamus. Journal of Neuroendocrinology $\mathbf{8}$, 733-735.

Mercer JG, Hoggard N, Williams LM, Lawrence CB, Hannah LT \& Trayhurn P (1996c) Localization of leptin receptor mRNA and the long form splice variant (Ob-Rb) in mouse hypothalamus and adjacent brain regions by in situ hybridization. FEBS Letters 387, 113-116.

Mercer JG, Moar KM \& Hoggard N (1998) Localization of leptin receptor (Ob-R) messenger ribonucleic acid in the rodent hindbrain. Endocrinology 139, 29-34.

Mercer JG, Moar KM, Logie TJ, Findlay PA, Adam CL \& Morgan PJ (2001) Seasonally-inappropriate body weight induced by food restriction: effect on hypothalamic gene expression in male Siberian hamsters. Endocrinology 142, 4173-4181.
Mercer JG \& Speakman JR (2001) Hypothalamic neuropeptide mechanisms for regulating energy balance: from rodent models to human obesity. Neuroscience and Biobehavioral Reviews 25, 101-116.

Miller M, Duhl DM, Vrieling H, Cordes SP, Ollmann MM, Winkes BM \& Barsh GS (1993) Cloning of the mouse agouti gene predicts a secreted protein ubiquitously expressed in mice carrying the lethal yellow mutation. Genes and Development 7 , 454-467.

Miyawaki T, Hosoda K, Masuzaki H, Natsui K, Hanaoka I, Hiraoka J, Matsuoka N, Matsuda JI, Murata M, Matsuo T, Sugawara A \& Nishi S (1997) Regulation of plasma leptin levels by nutritional status in humans. Diabetes 46, 989.

Mizuno TM \& Mobbs CV (1999) Hypothalamic agouti-related protein messenger ribonucleic acid is inhibited by leptin and stimulated by feeding. Endocrinology 140, 814-817.

Montague CT, Farooqi IS, Whitehead JP, Soos MA, Rau H, Wareham NJ, Sewter CP, Digby JE, Mohammed SN, Hurst JA, Cheetham CH, Earley AR, Barnett AH, Prins JB \& O'Rahilly S (1997) Congenital leptin deficiency is associated with severe early-onset obesity in humans. Nature 387, 903-908.

Montague CT, Prins JB, Sanders L, Zhang JL, Sewter CP, Digby J, Byrne CD \& O'Rahilly S (1998) Depot-related gene expression in human subcutaneous and omental adipocytes. Diabetes $\mathbf{4 7}$, $1384-1391$.

Moran TH (2000) Cholecystokinin and satiety: current perspectives. Nutrition 16, 858-865.

Morgan PJ \& Mercer JG (2001) The regulation of body weight: lessons from the seasonal animal. Proceedings of the Nutrition Society 60, 127-134.

Mueller W, Gregoire FM, Stanhope KL, Mobbs CV, Mizuno TM, Warden CH, Stern JS \& Havel PJ (1998) Evidence that glucose metabolism regulates leptin secretion from cultural rat adipocytes. Endocrinology 139, 551-558.

Ollmann MM, Wilson BD, Yang YK, Kerns JA, Chen YR, Gantz I \& Barsh GS (1997) Antagonism of central melanocortin receptors in vitro and in vivo by Agouti-related protein. Science 278, 135-138.

Pelleymounter MA, Cullen MJ, Baker MB, Hecht R, Winters D, Boone T \& Collins F (1995) Effects of the obese gene product on body weight regulation in ob/ob mice. Science 269, 540-543.

Powley TL \& Keesey RE (1970) Relationship of body weight to the lateral hypothalamic feeding syndrome. Journal of Comparative Physiology and Psychology 70, 25-36.

Price RA \& Gottesman II (1991) Body fat in identical twins reared apart - roles for genes and environment. Behavior Genetics 21, $1-7$.

Qu D, Ludwig S, Gammeltoft S, Piper M, Pelleymounter MA, Cullen MJ, Mathes WF, Przypek J, Kanarek R \& Maratos-Flier E (1996) A role for melanin-concentrating hormone in the central regulation of feeding behaviour. Nature 380, 243-247.

Russell CD, Petersen RN, Rao SP, Ricci MR, Prasad A, Zhang Y, Brolin RE \& Fried SK (1998) Leptin expression in adipose tissue from obese humans: depot-specific regulation by insulin and dexamethasone. American Journal of Physiology 38, E507-E515.

Sakurai T, Amemiya A, Ishii M, Matsuzaki I, Chemelli RM, Tanaka H et al. (1998) Orexins and orexin receptors: a family of hypothalamic neuropeptides and $\mathrm{G}$ protein-coupled receptors that regulate feeding behaviour. Cell 92, 575-585.

Saltzman E \& Roberts SB (1995) The role of energy expenditure in energy regulation - findings from a decade of research. Nutrition Reviews 53, 209-220.

Satoh N, Katsuura G, Hayase M, Tsuji T, Takaya K \& Ogawa Y (1997) Dual effects of leptin on body weight regulation via the arcuate nucleus (Arc) and the ventromedial hypothalamus (VMH). Diabetes 46, 978. 
Schoeller DA, Cella LK, Sinha MK \& Caro JF (1997) Entrainment of the diurnal rhythm of plasma leptin to meal timing. Journal of Clinical Investigation 100, 1882-1887.

Schwartz GJ (2000) The role of gastrointestinal vagal afferents in the control of food intake: current prospects. Nutrition 16, 866-873.

Schwartz MW (1997) Regulation of appetite and body weight. Hospital Practice 32, 117-119.

Schwartz MW, Baskin DG, Bukowski TR, Kuijper JL, Foster D, Lasser G, Prunkard DE, Porte D, Woods SC, Seeley RJ \& Weigle DS (1996) Specificity of leptin action on elevated blood glucose levels and hypothalamic neuropeptide $\mathrm{Y}$ gene expression in ob/ob mice. Diabetes 45, 531-535.

Schwartz MW, Sipols AJ, Grubin CE \& Baskin DG (1993) Differential effect of fasting on hypothalamic expression of genes encoding neuropeptide Y, galanin, and glutamic acid decarboxylase. Brain Research Bulletin 31, 361-367.

Schwartz MW, Woods SC, Porte D, Seeley RJ \& Baskin DG (2000) Central nervous system control of food intake. Nature 404, 661-671.

Speakman JR, Trayhurn P \& Rayner DV (1999) Leptin inhibits the starvation responses of mice. FASEB Journal 13, A1027.

Stanley BG, Kyrkouli SE, Lampert S \& Leibowitz SF (1986) Neuropeptide Y chronically injected into the hypothalamus: a powerful neurochemical inducer of hyperphagia and obesity. Peptides 7, 1189-1192.

St Jeor ST (1997) New trends in weight management. Journal of the American Dietetic Association 97, 1096-1098.

Steinlechner S, Heldmaier G \& Becker H (1983) The seasonal cycle of body weight in the Djungarian hamster: Photoperiodic control and influence of starvation and melatonin. Oecologia $\mathbf{6 0}$, 401-405.

Taouis M, Dridi S, Cassy S, Benomar Y, Raver N, Rideau N, Picard M, Williams J \& Gertler A (2001) Chicken leptin: properties and actions. Domestic Animal Endocrinology 21, 319-327.

Tappy L, Binnert C \& Schneiter Ph (2003) Effects of nutrients intake on energy expenditure. Proceedings of the Nutrition Society 62 (In the Press).

Tartaglia LA, Dembski M, Weng X, Deng NH, Culpepper J, Devos R et al. (1995) Identification and expression cloning of a leptin receptor, OB- R. Cell 83, 1263-1271.

Tasaka Y, Yanagisawa K, Kawahara R \& Omori Y (1997) Plasma human leptin in obese and diabetic subjects and its diurnal variation. Diabetologia 40, 1051.

Turton MD, O'Shea D, Gunn I, Beak SA, Edwards CMB, Meeran K, Choi SJ, Taylor GM, Heath MM, Lambert PD, Wilding JPH, Smith DM, Ghatei MA, Herbert J \& Bloom SR (1996) A role for glucagon-like peptide-1 in the central regulation of feeding. Nature 379, 69-72.

Vaisse C, Clement K, Guy-Grand B \& Froguel P (1998) A frameshift mutation in human MC4R is associated with a dominant form of obesity. Nature Genetics 20, 113-114.

van Aggel-Leijssen DPC, Saris, WHM, Hul GB \& van Baak MA (2001) short-term effects of weight loss with or without low intensity exercise training on fat metabolism in obese men. American Journal of Clinical Nutrition 73, 523-531.

Vinten J, Stoving R, Handberg A \& Hagen C (1996) Diurnal variation of the plasma leptin concentration in anorexia nervosa patients and control subjects. Diabetologia 39, 550.

Vogler GP, Sorensen TIA, Stunkard AJ, Srinivasan MR \& Rao DC (1995) Influences of genes and shared family environment on adult body mass index assessed on an adoption study by a comprehensive path model. International Journal of Obesity 19, 40-45.

Wadden TA (1993) Treatment of obesity by moderate and severe calorific restriction. Results of clinical research trials. Annals of Internal Medicine 119, 688-693.

Wang TL, Hartzell DL, Flatt WP, Martin RJ \& Baile CA (1998) Responses of lean and obese Zucker rats to centrally administered leptin. Physiology and Behavior 65, 333-341.

Weigle DS (1994) Appetite and the regulation of body composition. Nature 8, 302-310.

Weigle DS, Bukowski TR, Foster DC, Holderman S, Kramer JM, Lasser G, Loftonday CE, Prunkard DE, Raymond C \& Gertler A (1995) Recombinant ob protein reduces feeding and body weight in the ob/ob mouse. Journal of Clinical Investigation 96, 2065-2070.

Weinsier RL, Hunter GR, Gower BA, Schutz Y, Darnell BE \& Zuckerman PA (2001) Body fat distribution in white and black women: different patterns of intra-abdominal and sub-cutaneous adipose tissue utilisation with weight loss. American Journal of Clinical Nutrition 74, 631-636.

Weintraub M (1992) Long-term weight control study: conclusions. Clinical Pharmacology Theory 51, 642-646.

Wilding JPH, Gilbey SG, Bailey CJ, Batt RA, Williams G, Ghatei MA \& Bloom SR (1993) Increased neuropeptide-Y messenger ribonucleic acid (mRNA) and decreased neurotensin mRNA in the hypothalamus of the obese (ob/ob) mouse. Endocrinology 132, 1939-1944.

Wirtshafter D \& Davis JD (1977) Set points, settling points, and the control of body weight. Physiology and Behavior 19, 75-78.

Woods S, Seeley R, Porte DJ \& Schwartz M (1998) Signals that regulate food intake and energy homeostasis. Science $\mathbf{2 8 0}$, $1378-1383$.

Woods SC, Seeley RJ \& Schwartz MW (1997) Leptin as an adiposity signal. Endocrinology and Metabolism 4, 77-79.

Yaswen L, Diehl N, Brennan MB \& Hochgeschwender U (1999) Obesity in the mouse model of pro-opiomelanocortin deficiency responds to peripheral melanocortin. Nature Medicine $\mathbf{5}$, 1066-1070.

Yeo GS, Farooqi IS, Aminian S, Halsall DJ, Stanhope RG \& O'Rahilly S (1998) A frameshift mutation in MC4R associated with dominantly inherited human obesity. Nature Genetics $\mathbf{2 0}$, 111-112.

Zhang Y, Proenca R, Maffei M, Barone M, Leopold L \& Friedman JM (1994) Positional cloning of the mouse obese gene and its human homologue. Nature 372, 425-432. 